\title{
Push, Pass, Pull Political Marketing Adnan Purichta Ichsan-Abdul Rauf Mallagani Pada Pemilihan Kepala Daerah di Kabupaten Gowa 2015
}

\author{
Nur Khaerah ${ }^{1}$ \\ Zaldi Rusnaedy ${ }^{2}$ \\ Universitas Muhammadiyah Makassar \\ Universitas Pancasakti \\ nurkhaerah@unismuh.ac.id
}

\begin{abstract}
This article analyzes Push, Pass, Pull Political Marketing Adnan Purichta IchsanAbdul Rauf Mallagani At the Election of Regional Heads in Gowa Regency 2015. This study uses qualitative research methodology, with data obtained through interviews, literature studies and documentation. The analysis technique uses data reduction, data presentation, and conclusion drawing. The results of the study show that 1). The results of the electability survey of JSI, LSI and IPI as well as the vision and mission that are used as selling political products can ultimately give influences to the formation of public opinion, so that voters solidify their choice of candidates who are marketed. This push-marketing strategy is carried out as a rational and emotional stimulant to voters. 2). The involvement of Ichsan's character in the political marketing pass strategy by Adnan's team was able to become the ideal influencer for rational voters and loyalists of Yasin Limpo's family in the 2015 Gowa Regency Election. 3) Strategy Pull Political Marketing whose expectations for forming Adnan's image is not optimal due to Ichsan's under the shadow. Even so, there are still efforts to form a positive political image. One of them is through branding on various media especially social media.
\end{abstract}

Keywords: Push, Pass, Pull Political Marketing; Winning Strategy, Local Election 


\begin{abstract}
ABSTRAK
Artikel ini menganalisis tentang Push, Pass, Pull Political Marketing Adnan Purichta Ichsan-Abdul Rauf Mallagani Pada Pemilihan Kepala Daerah di Kabupaten Gowa 2015. Penelitian ini menggunakan metodologi penelitian kualitatif, dengan data diperoleh melalui wawancara, studi pustaka dan dokumentasi. Teknik analisis menggunakan reduksi data, penyajian data, dan penarikan kesimpulan. Hasil penelitian menunjukkan bahwa 1). Hasil survey elektabilitas JSI, LSI dan IPI serta visi misi yang dijadikan sebagai jualan produk politik pada akhirnya dapat memberi influens terhadap pembentukan opini publik, sehingga pemilih memantapkan pilihannya pada kandidat yang dipasarkan. Strategi push-marketing ini dilakukan sebagai stimulan rasional dan emosional kepada pemilih. 2). Pelibatan Ketokohan Ichsan dalam strategi pass political marketing oleh tim Adnan mampu menjadi influencer yang ideal bagi pemilih rasional dan loyalis keluarga Yasin Limpo pada Pilkada Kabupaten Gowa tahun 2015. 3) Strategi Pull Political Marketing yang ekspektasinya untuk membentuk image ketokohan Adnan, belum maksimal dikarenakan under the shadow dari Ichsan. Meskipun demikian, tetap ada upaya untuk membentuk image politiknya yang positif. Salah satunya melalui branding di berbagai media khususnya media sosial.
\end{abstract}

Kata kunci: push, pass, pull political marketing; strategi pemenangan; pilkada 


\section{A. PENDAHULUAN}

Marketing politik (political marketing) atau diterjemahkan sebagai pemasaran politik, secara keilmuan dalam subdisiplin ilmu politik baru berkembang pada tahun 1980-an. Tetapi dalam penerapannya sudah banyak dilakukan, diantaranya penggunaan marketing dalam dunia politik yaitu tahun 1917 ketika Partai Buruh meresmikan departemen publikasi, sebagai media dan sarana dalam memperkenalkan atau mengkampanyekan Partai Buruh yang dibantu oleh agen publikasi Egerton Wake. Kemudian, Wring (1997) menyatakan jika partai-partai politik di Inggris telah cukup lama melakukan aktivitas marketing politik dan Partai Konservatif menjadi partai pertama yang menggunakan agen biro iklan (Holford-Bottomley Advertising Service) sejak masa periode pemilu tahun 1929. Aktivitas marketing politik yang dilakukannya yaitu membantu mendesain dan mendistribusikan poster dan pamflet (Firmanzah, 2012). Selanjutnya pada tahun 1979, saat terpilihnya Margaret Thatcher menjadi Perdana Menteri Inggris juga sudah menggunakan bantuan jasa marketing seperti radio dan televisi sebagai media kampanye.

Konsep marketing yang menjadi trend dunia sebagai strategi pemenangan dalam kontestasi politik. Konsep marketing telah memberi kontribusi dan pengaruh besar dalam arena kontestasi politik di berbagai negara. Nursal (2004) dalam analisisnya melihat bahwa tanda-tanda mulai diterapkannya konsep marketing dalam urusan politik yaitu saat televisi memainkan peran marketingnya dalam penyampaian pesan-pesan komersil kepada publik secara eksplisit, dan implementasi konsep marketing politik oleh Bill Clinton dalam persaingan menjadi Presiden Amerika dapat dianggap sebagai tonggak penting sejarah marketing politik.

Indonesia adalah negara yang terbilang responsif dalam mengadopsi berbagai macam trend dunia yang sedang booming, termasuk dalam urusan politik. Pasca Reformasi, memberi dampak pada perubahan kehidupan politik di Indonesia. Ruang-ruang sistem demokrasi langsung semakin terbuka, dan konsep 
marketing politik semakin banyak diaplikasikan oleh partai politik dan aktor-aktor politik.

Era reformasi ini banyak partai yang bermunculan bahkan mencapai 150 partai (Firmanzah, 2012). Tetapi, pada pemilu 1999 hanya 48 partai yang lolos verifikasi dan berhak sebagai peserta pemilu. Pemilu 2004 jumlah partai mengalami penurunan yaitu hanya 24 partai, kemudian pemilu 2009 kembali meningkat. Berdasarkan pasal 315 dan 316 UU No 10 tahun 2008 ditetapkan sebagai peserta Pemilu 2009 berjumlah 34 partai politik nasional dan 6 partai politik lokal Aceh (Kompas, 2008). Hingga pada pemilu 2014, terdapat 10 partai politik nasional dan 3 partai lokal aceh yang ditetapkan oleh KPU sebagai peserta Pemilu 2014 (detikNews, 2013).

Fenomena pasang surutnya jumlah partai yang berkompetisi disetiap periode pemilu memperlihatkan peran penting dari sebuah strategi partai politik dan para kandidat untuk survive disegala kondisi agar dapat menarik simpati masyarakat pemilih. Kondisi seperti inilah marketing politik mulai memainkan perannya. Tetapi secara bersamaan, pasca reformasi juga membuka ruang-ruang demokrasi yang menempatkan masyarakat sebagai penentu keberhasilan partai politik atau kandidat kepala daerah dalam memperoleh kursi jabatan politik. Undang-Undang Nomor 32 Tahun 2004 tentang Pemerintahan Daerah, menjadi legitimasi pemilihan kepala daerah dan wakil kepala daerah dilakukan secara langsung. Pilkada tidak lagi melalui Dewan Perwakilan Rakyat Daerah (DPRD), tentu hal ini menjadi tantangan baru dan semakin membuka peluang diliriknya konsep marketing politik sebagai strategi pemenangan.

Pemilihan kepala daerah dan wakil kepala daerah (Pilkada) secara langsung, untuk kali pertama dimulai pada bulan Juni 2005 sampai Juni 2008. Undang-Undang Nomor 32 Tahun 2004 kemudian direvisi menjadi UndangUndang Nomor 12 Tahun 2008 tentang pemilihan daerah. Undang-undang khusus yang membahas Pemilu dan Pilkada yaitu Undang-Undang Nomor 22 Tahun 2007 tentang Penyelenggara Pemilihan Umum, Undang-undang Nomor 8 Tahun 2015 Tentang Perubahan atas Undang-undang Nomor 1 Tahun 2015 Tentang Penetapan 
Peraturan Pemerintah Pengganti Undang-undang Nomor 1 Tahun 2014 Tentang Pemilihan Gubernur, Bupati, dan Wali Kota Menjadi Undang-undang. UndangUndang nomor 1 tahun 2014 tentang Pemilihan Gubernur, Bupati, dan Walikota, Pemerintah kemudian menggantinya menjadi Undang-Undang Nomor 1 tahun 2015. Undang-Undang ini kembali diubah menjadi Undang-Undang Nomor 8 tahun 2015.

Regulasi-regulasi ini membuka ruang kepada masyarakat untuk turut berpartisipasi dalam politik seperti contoh menjadi calon Kepala Daerah dan Wakil Kepala Daerah tanpa kendaraan partai politik atau istilah lainnya melalui jalur Independen (Perseorangan). Melalui Undang-Undang Nomor 8 tahun 2015 tentang Pilkada, pada Pasal 42 secara tegas mengatakan pasangan calon kepala dan wakil kepala daerah dapat diajukan secara perseorangan apabila mereka dapat mengumpulkan dukungan berupa kartu identitas penduduk (KTP) sebanyak 6,5 hingga 10 persen dari total jumlah Daftar Pemilih Tetap (DPT) dalam Pilkada sebelumnya.

Tahun 2015 menjadi momentum pesta demokrasi yang lebih tersturktur dibandingkan Pilkada-pilkada sebelumnya. Sistem pemilihan kepala daerah secara langsung dan serentak serta penerapan sistem multi partai ini menyebabkan persaingan yang terbuka diantara kadidat kepala daerah dalam memperoleh simpati dan suara rakyat. Begitu ketatnya persaingan, calon incumbent atau petahana tidak memiliki jaminan sebagai pemenang pilkada berikutnya. Firmanzah (2008,2012), Alwie (2012), dan Butler \& Collins (2001) memiliki pandangan yang sama jika perilaku pemilih bersifat dinamis yang cenderung berubah-ubah. Politisi dan partai politik perlu untuk selalu memperbaharui strategi pemenangannya termasuk pola-pola marketing politiknya.

Pilkada serentak yang berlangsung pada 2015 lalu, yang dilaksanakan di 9 provinsi, 36 kota dan 224 kabupaten dengan 136 pasangan calon (paslon) yang mendaftarkan diri sebagai calon perseorangan untuk ikut berkompetisi dalam pemilihan kepala dan wakil kepala daerah, akhirnya 12 pasangan calon jalur independen yang menang pada pilkada tersebut (liputan6.com). Salah satu 
provinsi yang melaksanakan pilkada serentak adalah Sulawesi Selatan. Dari 36 pasangan sebanyak 29 pasangan diusung partai politik dan 7 pasangan dari jalur perseorangan/independen, mereka tersebar diempat kabupaten seperti Kabupaten Bulukumba, Pangkep, Gowa dan Soppeng.

Salah satu kabupaten di Provinsi Sulawesi Selatan yang menarik perhatian untuk dijadikan sebagai locus penelitian adalah Kabupaten Gowa. Ada fenomena yang berbeda dan menarik dibandingkan daerah lainnya, diantaranya dalam kontestasi Pilkada Kabupaten Gowa yang diikuti dua kandidat dari keluarga yang sama. Purwaningsih (2015) dan Rusnaedy (2018), menyebutnya sebagai Keluarga Politik Yasin Limpo atau Klan politik Yasin Limpo. Dalam sejarahnya, klan politik Yasin Limpo selama lima kali penyelengaraan Pilkada secara berturut-turut (23 tahun) baik Pilkada langsung maupun tidak langsung semuanya dimenangkan keluarga Yasin Limpo.

Pilkada Kabupaten Gowa tahun 2015, dimana dua anggota keluarga Yasin Limpo yang saling berkompetisi memperebutkan kursi Bupati Kabupaten Gowa adalah Adnan Purichta Ichsan dan Tenri Olle Yasin Limpo. Tenri Olle merupakan anak dari Muhammad Yasin Limpo sedangkan Adnan Purichta merupakan cucu Yasin Limpo, juga anak dari Ichsan (Bupati Gowa dua periode sebelum Adnan) yang tak lain adalah saudara kandung dari Tenri Olle. Restuti (2016) menyebut pertarungan ini adalah sebuah tantangan berat karena sebagai rumpun keluarga yang memiliki irisan basis pendukung sama. Namun, kompetisi ini bisa saja keterlibatan tokoh Ichsan memengaruhi kebijakan yang ada untuk memenangkan Adnan (Badjuri \& Yuwono, 2007).

Hal lainnya yang menarik perhatian, dari 7 pasangan jalur perseorangan di Sulawesi Selatan, Adnan-Kio adalah satu-satunya kadidat kepala daerah yang berhasil memenangkan kompetisi dalam Pilkada. Serta dalam pertarungan ini, Andi Maddusila Andi Idjo yang merupakan Raja Gowa yang telah beberapa kali menjadi peserta Pilkada menjadi rival yang cukup kuat tetapi ditaklukkan oleh pasangan Adnan-Kio. Melihat fakta empiris, pasangan Adnan-Kio yang berhasil memenangkan kontestasi Pilkada Kabupaten Gowa pada tahun 2015, adalah 
fenomena yang menarik untuk dikaji. Olehnya itu, berdasarkan uraian di atas, penelitian ini bertujuan untuk menganalisis Strategi Marketing Politik Pemenangan Adnan Purichta Ichsan-Abdul Rauf Mallagani Pada Pemilihan Kepala Daerah di Kabupaten Gowa 2015. Penelitian ini menggunakan pendekatan teori Strategi Marketing Politik dari Nursal (2004) yaitu Push political marketing, pass political marketing dan Pull political marketing.

\section{B. METODE PENELITIAN}

Artikel ini berangkat dari hasil penelitian yang menggunakan pendekatan penelitian kualitatif. Pendekatan penelitian kualitatif bermaksud untuk memahami tentang apa yang dialami oleh subjek penelitian dengan cara deskripsi dalam bentuk kata-kata dan bahasa dengan memanfaatkan berbagai metode alamiah (Moleong, 2007:6). Data-data yang digunakan dalam penelitian ini didapatkan dari kandidat dan masing-masing tim sukses atau tim pemenangan Adnan Purichta Ichsan-Abdul Rauf Mallagani. Teknik pengumpulan data yang digunakan yaitu dokumentasi dari sumber-sumber tertulis dan wawancara. Studi dokumentasi dilakukan mengenai profil kandidat, perolehan suara, harta kekayaan pribadi, dan dana sumbangan kampanye dan hal yang paling penting adalah strategi marketing politik yang dilakukannya. Wawancara dilakukan kepada kandidat, partai pengusung dan tim sukses. Penemuan sumber data pada orang yang diwawancarai dilakukan secara purposive sampling, yaitu dipilih dengan sengaja dengan pertimbangan dan tujuan tertentu.

\section{HASIL DAN PEMBAHASAN}

Hasil penelitian menunjukkan bahwa dalam Pilkada Kabupaten Gowa tahun 2015 pasangan Adnan-Kio mengalahkan empat kompetitor lainnya dengan presentase 41,65\%. Kemenangan Adnan diperoleh tidak terlepas dari varian strategi yang diaplikasikan pada saat kampanye politik. Strategi yang dilakukan yang memiliki dampak paling signifikan terhadap kemenangan Adnan adalah faktor determinan dari Ichsan Yasin Limpo (orang tua dan bupati sebelumnya). 
Dalam artikel ini digunakan tiga bentuk strategi kampanye (dalam penelitian ini diistilahkan sebagai marketing politic) untuk menganalisis kemenangan Adnan yaitu push political marketing, pull political marketing dan pass political marketing.

\section{a. Push Political Marketing}

Push political marketing didefinisikan sebagai sebuah pemasaran produk politik secara langsung ke calon pemilih. Fokus utama dari strategi ini lebih kepada isu-isu yang penting (produk politik) bagi pemilih dan bukan hanya menjual kandidat atau partai. Produk politik berusaha mendapatkan dukungan melalui stimulan berupa sejumlah alasan rasional dan emosional untuk menggerakan massa demi mendukung kandidat. Produk politik disampaikan kepada konstituen melalui media (cetak, elektronik dan daring) dan influencer group sebagai distributor pesan (Nursal, 2004).

Sebagai sebuah strategi kampanye politik, push political marketing digunakan dalam arena pertarungan politik demi sebuah kemenangan. Hal tersebut dilakukan oleh Adnan dalam bentuk strategi push political marketingnya dengan membentuk dan memengaruhi opini publik melalui survei elektabilitas dan visi misi yang menjadi preferensi sebagai produk politik.

Sebagai salah satu produk politik, survei elektabilitas biasanya dijadikan sebagai bahan rujukan untuk menentukan pilihan, baik itu partai politik maupun masyarakat terhadap kandidat. Hasil survei mempunyai pengaruh besar dalam kampanye politik. Hal ini terutama apabila dikaitan dengan favorit atau tidaknya kandidat (Cangara, 2011:142; Kurniawan, 2015). Meski hanya bersifat kajian, namun dalam perkembangannya hasil survei dapat memengaruhi konstelasi politik. Hasil survei secara tidak langsung akan memperlihatkan konstelasi atau tatanan politik yang terbangun di lingkungan masyarakat hingga perilaku pemilih yang dikaitkan dengan situasi terkini. Pelbagai informasi tersebut bisa menjadi pedoman bagi kandidat dan tim sukses dalam mengambil langkah politik atau menyusun strategi kampanye dan taktik pemenangan. 
Hasil survei juga bisa memberikan arah bagaimana komposisi perilaku undicided voters dan swing voters, hal-hal apa saja yang bisa mempersuasi para pemilih hingga isu yang bisa memperkuat segmentasi para pemilih sosiologis dan psikologis berdasarkan wilayah. Bagi kandidat dan tim sukses hasil survei bisa dijadikan alat untuk menggiring opini masyarakat dan mobilisasi pemenangan.

Pada Pilkada Kabupaten Gowa tahun 2015 terdapat tiga hasil lembaga survei terhadap lima pasangan calon kepala daerah yaitu yang dilakukan oleh Jaringan Suara Indonesia (JSI), Lingkaran Survey Indonesia (LSI) dan Indeks Politica Indonesia (IPI). Meskipun ketiga lembaga survei tersebut merilis hasil survei yang berbeda tetapi ketiganya menempatkan posisi pertama dan kedua pasangan yang paling popular dari keluarga Yasin Limpo.

\section{Tabel 1. Hasil Survei Elektabilitas Calon Kepala Daerah dan Wakil Kepala}

Daerah Kabupaten Gowa Tahun 2015

\begin{tabular}{|c|c|c|c|c|}
\hline $\begin{array}{l}\text { No. } \\
\text { Urut }\end{array}$ & $\begin{array}{c}\text { Calon Kepala Daerah dan } \\
\text { Wakil Kepala Daerah } \\
\text { Kabupaten Gowa Tahun } \\
2015 \\
\end{array}$ & IPI & LSI & JSI \\
\hline 1 & $\begin{array}{l}\text { Andi Maddusila A Idjo - } \\
\text { Wahyu Permana Kaharuddin }\end{array}$ & 22,40 & 24 & 28,4 \\
\hline 2 & $\begin{array}{l}\text { Syahrir Syarifuddin Daeng } \\
\text { Jarung - Anwar Usman }\end{array}$ & 4,2 & 4,5 & 1,8 \\
\hline 3 & $\begin{array}{l}\text { Djamaluddin Maknun - } \\
\text { Masjkur }\end{array}$ & 2 & 2,1 & 1,1 \\
\hline 4 & Tenri Olle YL - Hairil Muin & 35,1 & 33,8 & 23 \\
\hline 5 & $\begin{array}{l}\text { Purichita Ichsan YL - Abd } \\
\text { Rauf Kr Kio }\end{array}$ & 30,40 & 30,2 & 45,7 \\
\hline
\end{tabular}

Sumber: diolah oleh penulis dari berbagai sumber.

Menanggapi hasil survei elektabilitas dari pelbagai lembaga survey, Ketua

PAN DPD Gowa menuturkan bahwa hasil survei Adnan melebihi angka rata-rata dari kandidat lainnya, sehingga tidak ada pilihan lain untuk tidak memilih AdnanKio (Wawancara dengan Ketua PAN Gowa, 4 Mei 2017). Tingginya elektabilitas 
kedua kandidat dibandingkan dengan calon lainnya menjadi modal politik yang dapat memengaruhi pilihan masyarakat untuk memantapkan pilihannya kepada Adnan. Meskipun hanya sebatas kajian, sebuah hasil survei dapat memengaruhi konstelasi politik, baik untuk kandidat maupun bagi pemilih.

Bagi kandidat, hasil survei elektabilitas dapat dijadikan sebagai pedoman dalam menentukan langkah politik dan menyusun strategi kampanye atau marketing politik bersama tim suksesnya. Sementara bagi masyarakat, hasil survei bisa memberikan pengaruh kepada calon pemilih mengambang atau yang belum menentukan pilihan. Pada dasarnya, hasil survei memberikan pengaruh terhadap Pilkada baik bagi kandidat dan tim suksesnya maupun bagi masyarakat untuk menentukan pilihannya. Dalam penelitian ini melihat bahwa salah satu rujukan masyarakat dalam menentukan pilihannya pada Adnan dilatarbelakangi oleh tingginya elektabilitas Adnan yang tersebar di berbagai media baik cetak maupun online serta media sosial.

Fenomena ini menunjukkan bahwa survei elektabilitas menjadi bagian dari produk politik Adnan, yang menjadi jualannya pada masa kampenye politik. Selain survei elektabilitas, visi-misi Adna-Kio yang menawarkan peningkatan kesehatan gratis, melanjutkan pendidikan gratis, peningkatan pertanian dan pembangunan infrastruktur jalan dengan alokasi $20 \%$ tiap tahun dari APBD, merupakan tawaran produk politik yang menunjang peningkatan elektabilitasnya.

Visi misi yang ditawarkan Adnan merupakan keberlanjutan dari produk kebijakan Ichsan selama menjabat 2 periode, yang memperoleh indeks kepuasan masyarakat Kabupaten Gowa pada bidang pendidikan dengan tingkat kepuasan paling tinggi mencapai 94\%, kemudian bidang kesehatan dengan persentase sebesar 88,9\%, sedangkan di bidang ekonomi mencapai 63\%. Pendidikan dan kesehatan gratis adalah produk politik andalannya dalam mencapai strategi push political marketing.

\section{b. Pass Political Marketing}

Pembentukan opini publik melalui survei elektabilitas sebagai salah satu strategi yang digunakan Adnan selain menggunakan strategi pass political 
marketing. Hal tersebut didefinisikan sebagai sebuah strategi kampanye politik yang menggunakan individu untuk memengaruhi opini konstituen. Sukses atau tidaknya mendulang suara bergantung tepat atau tidaknya pemilihan influencer.

Semakin tepat influencer dipilih, maka semakin besar pula efek yang ditimbulkan dalam memengaruhi keyakinan konstituen dalam memilih kandidat. Adnan menggunakan Ichsan sebagai tokoh sentral dalam upaya memengaruhi baik partai politik maupun publik untuk memilihnya. Selain sebagai bupati dua periode, Ichsan juga dikenal sebagai tokoh Kabupaten Gowa yang mulai dibangun oleh orang tuanya Muhammad Yasin Limpo yang pernah menjadi Pejabat Bupati di Kabupaten Gowa dan beberapa daerah lainnya. Kemudian dilanjutkan oleh anaknya, Syahrul Yasin Limpo yang menjadi Bupati Gowa (1994-2002). Dengan rentang waktu yang relatif lama tersebut, tentunya keluarga Yasin Limpo telah menanamkan begitu banyak modal sosial kepada Masyarakat Kabupaten Gowa. Sehingga dalam setiap pemilihan kepala daerah di Kabupaten Gowa selalu dimenangkan oleh keluarga Yasin Limpo.

Modal sosial yang telah ditanamkan oleh Ichsan selama menjabat bupati dua periode kemudian dimanfaatkan oleh Adnan. Modal tersebut adalah kantongkantong kemenangan serta tim-tim yang sudah solid dan matang. Ichsan Yasin Limpo merawat jaringan tersebut sehingga pada Pilkada Gowa tahun 2015, Adnan tinggal memanfaatkannya. Kantong-kantong kemenangan dan tim yang sudah matang inilah yang menjadi keunggulan dari Adnan dibanding calon lainnya (Rusnaedy, 2018b).

Tabel 2. Perbandingan Perolehan suara Ichsan dan Adnan

\begin{tabular}{|c|l|c|c|c|}
\hline \multirow{2}{*}{ No } & \multirow{2}{*}{ Kecamatan } & $\begin{array}{c}\text { Tahun } \\
\text { Puara Ichsan } \\
(\mathbf{2 0 0 5})\end{array}$ & $\begin{array}{c}\text { Perolehan } \\
\text { Suara Ichsan } \\
\mathbf{( 2 0 1 0 )}\end{array}$ & $\begin{array}{c}\text { Perolehan } \\
\text { Suara Adnan } \\
(\mathbf{2 0 1 5})\end{array}$ \\
\hline $\mathbf{1}$ & Bontonompo & 9.184 & 16.506 & 11.356 \\
\hline $\mathbf{2}$ & Bontonompo Selatan & 6.323 & 10.555 & 7.958 \\
\hline $\mathbf{3}$ & Bajeng & 11.678 & 21.063 & 15.473 \\
\hline $\mathbf{4}$ & Bajeng Barat & - & 7.564 & 7.343 \\
\hline $\mathbf{5}$ & Pallangga & 10.083 & 23.857 & 19.726 \\
\hline
\end{tabular}




\begin{tabular}{|c|c|c|c|c|}
\hline 6 & Barombong & 4.651 & 10.393 & 7.767 \\
\hline 7 & Sombaopu & 11.713 & 23.418 & 20.847 \\
\hline 8 & Bontomarannu & 3.730 & 6.048 & 8.419 \\
\hline 9 & Pattalassang & 2.518 & 5.092 & 7.298 \\
\hline 10 & Parangloe & 3.208 & 5.852 & 4.187 \\
\hline 11 & Manuju & 4.474 & 4.770 & 5.723 \\
\hline 12 & Tinggimoncong & 4.851 & 6.802 & 2.973 \\
\hline 13 & Tombolo Pao & 3.505 & 8.803 & 5.569 \\
\hline 14 & Parigi & - & 5.368 & 2.617 \\
\hline 15 & Bungaya & 2.619 & 5.691 & 3.496 \\
\hline 16 & Bontolempangan & 3.759 & 4.576 & 4.669 \\
\hline 17 & Tompobulu & 6.254 & 8.598 & 8.604 \\
\hline 18 & Biringbulu & 9.686 & 9.672 & 7.749 \\
\hline & Jumlah & 98.336 & 184.628 & 151.373 \\
\hline
\end{tabular}

Sumber: Rusnaedy, 2018

Peran Ichsan dalam memobilisir simpul-simpul kekuatan yang telah dibangun dalam waktu relatif lama memiliki dampak signifikan terhadap kemenangan Adnan. Selain itu, relasi Ichsan ke beberapa partai turut menjadi modal untuk mendulang suara. "Adnan ini tidak terlalu diperhitungkan untuk kancah perpolitikan di Kabupaten Gowa, yang diperhitungkan itu bapaknya, karena bapaknya berhasil menanamkan pondasi di Gowa sehingga memunculkan anaknya. Orang melihat bukan Adnanya dulu tapi Ichsannya, olehnya itu PAN mendukung Adnan” (Wawancara pribadi dengan Ketua PAN Gowa 4 Mei 2017).

Pelibatan Ichsan dalam strategi pass political marketing oleh tim Adnan mampu menjadi influencer yang ideal bagi pemilih rasional dan loyalis keluarga Yasin Limpo pada Pilkada Kabupaten Gowa tahun 2015. Di sisi lain, simpulsimpul kekuatan seperti jaringan di lingkup birokrasi yang masih menokohkan Ichsan turut membantu dalam proses mobilisasi dukungan melalui birokrasi daerah hingga ke tingkat desa. Dalam penelitian sebelumnya, Rusnaedy (2018) menyebut kepala desa tidaklah memiliki hubungan secara struktural dengan Ichsan karena bukan pegawai pemerintah daerah, tetapi mereka dapat dipengaruhi melalui hubungan mereka dengan program-program pemerintah daerah yang dapat dijadikan alat untuk membangun kepatuhan terhadap keinginan birokrasi dan siapa yang memengaruhinya. 


\section{c. Pull Political Marketing}

Ichsan menjadi tokoh sentral dalam kemenangan Adnan pada Pilkada Kabupaten Gowa tahun 2015. Sehingga dengan terpilihnya Adnan melanjutkan kedigdayaan keluarga politik Yasin Limpo di Kabupaten Gowa selama lebih dari dua dekade. Adnan sebagai 'penerus tahta' kekuasaan tidak bisa melepaskan diri dari bayang-bayang ketokohan Ichsan, meskipun sebenarnya Adnan menjadi tokoh pemuda di bidang politik dengan penghargaan sebagai The Best Young of Politic dari Harmawan Kartajaya. Hanya saja dalam kontestasi Pilkada Kabupaten Gowa tahun 2015 tetap saja menjadi under the shadow dari Ichsan. Sebagaimana yang diungkapkan sendiri oleh Adnan "Tentu modal kemenangan saya pada Pilkada kemarin tidak lepas dari kesuksesan ayah saya selama memimpin Kabupaten Gowa. Kesuksesan ayah saya memimpin Kabupaten Gowa yang bisa diarasakan seluruh masyarakat itulah yang yang akhirnya saya tuai pada saat saya maju menjadi calon bupati” (Wawancara dengan Adnan, 13 Juli 2017).

Meskipun ketokohan Adnan terkesan under the shadow dari Ichsan, tetap ada upaya untuk membentuk image politiknya yang positif. Salah satunya melalui branding di berbagai media dan media sosial. Adnan dipersepsikan oleh pemilih sebagai figur yang energik dengan latar belakang pengalaman yang luwes karena berasal dari politisi muda. Pendapat ini dibenarkan oleh Silaban (2016) dalam penelitiannya menjelaskan sepak terjang Ichsan dalam dunia politik yang pernah menjabata sebagai anggota DPRD Provinsi Sulawesi Selatan selama dua periode. Figur dan ketokohan Adnan juga semakin terlihat setelah survei opini publik terkait Pilkada di Kabupaten Gowa yang dilakukan oleh lembaga survei Celebes Research Centre 2014, satu tahun sebelum pilkada. Adnan berhasil menempati urutan ke dua setelah Tenri Olle Yasin Limpo dengan selisih 3,8\% margin of error (MoE: $\pm 5 \%$ ). Artinya, branding image dan ketokohan Adnan sejak 2014 sudah berhasil meyakinan dan membangun opini masyarakat pemilih jika Adnan adalah figur yang tepat sebagai calon kepada daerah Kabupaten Gowa.

Branding image dalam penelitian ini disebut sebagai strategi Pull political marketing yang sejatinya menitikberatkan pada pembentukan image politik yang 
positif. Sebagaimana yang telah dijelaskan di atas, faktor kemenangan Adnan merupakan mutlak faktor determinan dari ketokohan Ichsan. Sehingga posisi Adnan dalam strategi Pull political marketing ini dapat dikata belum maksimal membangun image politiknya di tengah masyarakat Kabupaten Gowa.

\section{KESIMPULAN}

Pilkada Kabupaten Gowa tahun 2015 pasangan Adnan-Kio mengalahkan empat kompetitor lainnya dengan presentase 41,65\%. Kemenangan Adnan diperoleh tidak terlepas dari varian strategi yang diaplikasikan pada saat kampanye politik. Terdapat tiga bentuk strategi kampanye (dalam penelitian ini diistilahkan sebagai marketing politik) yang digunakan untuk menganalisis kemenangan Adnan yaitu push political marketing, pull political marketing dan pass political marketing. Hasil survey elektabilitas JSI, LSI dan IPI serta visi misi yang dijadikan sebagai jualan produk politik pada akhirnya dapat memberi influens terhadap pembentukan opini publik, sehingga pemilih memantapkan pilihannya pada kandidat yang dipasarkan. Strategi push-marketing ini dilakukan sebagai stimulan rasional dan emosional kepada pemilih. Selain itu, pelibatan Ichsan dalam strategi pass political marketing oleh tim Adnan mampu menjadi influencer yang ideal bagi pemilih rasional dan loyalis keluarga Yasin Limpo pada Pilkada Kabupaten Gowa tahun 2015. Selanjutnya, strategi Pull Political Marketing yang ekspektasinya untuk membentuk image ketokohan Adnan, belum maksimal dikarenakan under the shadow dari Ichsan. Meskipun demikian, tetap ada upaya untuk membentuk image politiknya yang positif. Salah satunya melalui branding di berbagai media dan media sosial. 


\section{DAFTAR PUSTAKA}

Adman, Nursal. (2004). Political Marketing Strategi Memenangkan Pemilu Sebuah Pendekatan Baru Kampanye Pemilihan DPR DPD Presiden Jakarta: Gramedia Pustaka Utama.

Admin. (2013, 8 Januari). KPU Tetapkan 10 Parpol Sebagai Peserta Pemilu Tahun $2014 \quad$ https://nasional.kompas.com/read/2008/07/07/ 23212471/daftar.parpol.peserta.pemilu.2009.

Admin. (2013, 8 Januari) https://news.detik.com/berita/2135677/kpu-tetapkan-10parpol-sebagai-peserta-pemilu-tahun-2014.

Alwie, Alvi Furwanti. (2012). Pemasaran Politik dan Keputusan Memilih Partisipan Pemilihan Kepala Daerah Pada Kelompok Perkotaan dan Kelompok Pinggiran Kota (Studi Pada Kelompok Partisipan Politik di Kota Pekanbaru). Jurnal Sosial Ekonomi Pembangunan Tahun II No. 6, Juli.

Badjuri A. \& Yuwono T. (2007). Kebijakan Publik, Konsep dan Strategi. Semarang: Universitas Diponegoro Press.

Butler, P., \& Collins, N (2001).” Political Marketing; Structure And Process," European Journal of Marketing Vol 28/No.1.

Cangara, Hafied. (2011). Komunikasi Politik: Konsep, Teori dan Strategi. Jakarta: Rajawali Press.

Firmanzah. (2008). Mengelola partai politik: Komunikasi dan Positioning Ideologi Politik di Era Demokrasi. Jakarta: Yayasan Obor Indonesia.

Firmanzah. (2012). Marketing Politik Antara Pemahaman dan Realitas. Jakarta: Yayasan Obor Indonesia.

Harisson, Lisa. (2009) Artikel ini telah tayang di kompas.com dengan judul "Daftar Parpol Peserta Pemilu 2009".

Kurniawan. (2015). "Pengaruh Hasil Survei Tentang Elektabilitas CapresCawapres 2014 Terhadap Perilaku Pemilih Di Surabaya.” Dalam Jurnal 
Rivew Politik. Surabaya : Democration and Regional Studies. Vol 5, Nomor 1, Juni 2015.

Moleong, Lexy J. (2007). Metodologi Penelitian Kualitatif (Edisi Revisi). Bandung: PT. Remaja Rosdakarya.

Restuti H. (2016). Pertarungan Antar Keluarga Pada Pilkada Gowa 2015: Suatu Studi Strategi Komunikasi Meraih Suara Pemilih. Makassar: Pascasarjana Universitas Hasanuddin.

Rusnaedy, Z., \& Purwaningsih, T. (2018). Keluarga Politik Yasin Limpo Pada

Pemilihan Kepala Daerah di Kabupaten Gowa Tahun 2015. Jurnal Politik, $3(2), 301-322$.

Rusnaedy, Zaldi. (2018b). Analisis Modalitas Keluarga Politik Yasin Limpo Pada

Pemilihan Kepala Daerah di Kabupaten Gowa Tahun 2015. Ringkasan

Tesis. Yogyakarta: UMY.

Silaban, Ahmad Harianto. (2016). Peluang dan Tantangan Pemuda Dalam Pemilihan Kepala Daerah: Studi Kasus di kabupaten Gowa Tahun 2015. The Politics: Jurnal Magister Ilmu Politik Universitas Hasanuddin. Vol. 2 No. 2, Juli 2016 | P-Issn: 2407-9138.

Purwaningsih, Titin. (2015). Politik Kekerabatan dan Kualitas Kandidat di Sulawesi Selatan.» Jurnal Politik 1 (1): 97-124.

Wring, D. (1997). Reconciling Marketing with Political Science : Theories of Political Marketing. Proceeding of the Academy of Marketing Conference, Manchester University. 